\title{
Reference
}

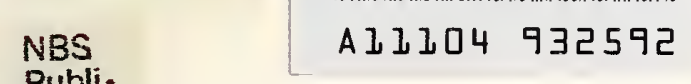

\section{Publi- cations}

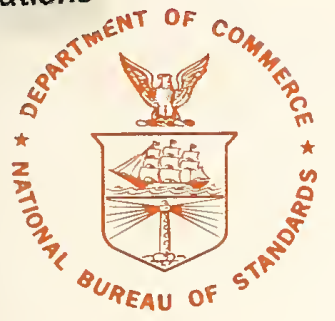

\section{American National Standard N542;}

\section{Sealed Radioactive Sources,}

\section{Classification}

$Q C$

1

.451

No. 126

1978 . 


\section{NATIONAL BUREAU OF STANDARDS}

The National Bureau of Standards' was established by an act of Congress March 3, 1901. The Bureau's overall goal is to strengthen and advance the Nation's science and technology and facilitate their effective application for public benefit. To this end, the Bureau conducts research and provides: (1) a basis for the Nation's physical measurement system, (2) scientific and technological services for industry and government, (3) a technical basis for equity in trade, and (4) technical services to promote public safety. The Bureau's technical work is performed by the National Measurement Laboratory, the National Engineering Laboratory, and the Institute for Computer Sciences and Technology.

THE NATIONAL MEASUREMENT LABORATORY provides the national system of physical and chemical and materials measurement; coordinates the system with measurement systems of other nations and furnishes essential services leading to accurate and uniform physical and chemical measurement throughout the Nation's scientific community, industry, and commerce; conducts materials research leading to improved methods of measurement, standards, and data on the properties of materials needed by industry, commerce, educational institutions, and Government; provides advisory and research services to other Government Agencies; develops, produces, and distributes Standard Reference Materials; and provides calibration services. The Laboratory consists of the following centers:

\section{Absolute Physical Quantities ${ }^{2}$ - Radiation Research - Thermodynamics and Molecular Science - Analytical Chemistry - Materials Science.}

THE NATIONAL ENGINEERING LABORATORY provides technology and technical services to users in the public and private sectors to address national needs and to solve national problems in the public interest; conducts research in engineering and applied science in support of objectives in these efforts; builds and maintains competence in the necessary disciplines required to carry out this research and technical service; develops engineering data and measurement capabilities; provides engineering measurement traceability services; develops test methods and proposes engineering standards and code changes; develops and proposes new engineering practices; and develops and improves mechanisms to transfer results of its research to the utlimate user. The Laboratory consists of the following centers:

Applied Mathematics - Electronics and Electrical Engineering ${ }^{2}$ - Mechanical

Engineering and Process Technology ${ }^{2}-$ Building Technology - Fire Research -

Consumer Product Technology — Field Methods.

THE INSTITUTE FOR COMPUTER SCIENCES AND TECHNOLOGY conducts research and provides scientific and technical services to aid Federal Agencies in the selection, acquisition, application, and use of computer technology to improve effectiveness and economy in Government operations in accordance with Public Law 89-306 (40 U.S.C. 759), relevant Executive Orders, and other directives; carries out this mission by managing the Federal Information Processing Standards Program, developing Federal ADP standards guidelines, and managing Federal participation in ADP voluntary standardization activities; provides scientific and technological advisory services and assistance to Federal Agencies; and provides the technical foundation for computer-related policies of the Federal Government. The Institute consists of the following divisions:

Systems and Software - Computer Systems Engineering - Information Technology.

'Headquarters and Laboratories at Gaithersburg, Maryland, unless otherwise noted;

mailing address Washington,D.C. 20234.

${ }^{2}$ Some divisions within the center are located at Boulder, Colorado, 80303. 
American National Standard N542; Sealed Radioactive Sources, Classification

American National Standards Institute Subcommittee N43-3.3

Under the sponsorship of the National Bureau of Standards Washington, D.C. 20234

Approved November 9, 1977

American National Standards Institute

New York, N.Y. 10018

ANSI N542-1977

(Revision of N5.10-1968)

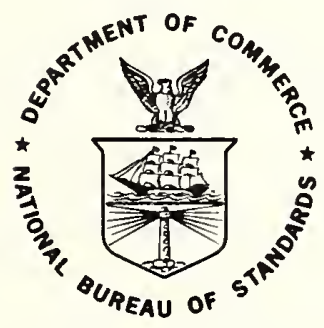

U.S. DEPARTMENT OF COMMERCE, Juanita M. Kreps, Secretary

Dr. Sidney Harman, Under Secretary

Jordan J. Baruch, Assistant Secretary for Science and Technology

NATIONAL BUREAU OF STANDARDS, Ernest Ambler, Director

Issued July 1978 
National Bureau of Standards Handbook 126

Nat. Bur. Stand. (U.S.), Handb.126, 28 pages (July 1978)

CODEN: NBSHAP

\section{U.S. GOVERNMENT PRINTING OFFICE}

iVASHINGTON: 1978

For sale by the Superintendent of Documents, U.S. Government Printing Office, Washington, D.C. 20402 (Order by SD Stock No. 003-003-01903-8.) Price \$1.20.

(Add 25 percent additional for other than U.S. mailing.) 


\section{American National Standard}

An American National Standard implies a consensus of those substantially concerned with its scope and provisions. An American National Standard is intended as a guide to aid the manufacturer, the consumer, and the general public. The existence of an American National Standard does not in any respect preclude anyone, whether he has approved the standard or not, from manufacturing, marketing, purchasing, or using products, processes, or procedures not conforming to the standard. American National Standards are subject to periodic review and users are cautioned to obtain the latest editions. Producers of goods made in conformity with an American National Standard are encouraged to state in their own advertising, promotion material, or on tags or labels, that the goods are produced in conformity with particular American National Standards.

CAUTION NOTICE. This American National Standard may be revised or withdrawn at any time. The procedures of the American National Standards Institute require that action be taken to reaffirm, revise, or withdraw this standard no later than five (5) years from the date of publication. Purchasers of American National Standards may receive current information on all standards by calling or writing the American National Standards Institute, 1430 Broadway, New York, New York 10018. 


\section{Preface}

(This Preface is not a part of American National Standard N542, Sealed Radioactive Sources, Classification.)

\section{Revised Standard-1977}

Work on this standard was begun in 1962 and culminated in publication in 1968 as ANSI N5.10. When the original standard was in its final draft form a copy was sent to the International Standards Organization (ISO). The ISO had been working on standards for sealed sources for several years. When the ANSI version was examined, the ISO Aecided to adopt the ANSI concept and general format.

ANSI procedures require that a standard be reviewed every five years. In 1973 when ANSI N5.10 was reviewed, it was decided to, essentially, duplicate the ISO version in its final draft form which was published as ISO/DIS 2919 in November 1972. Although the ANSI version contained sections on Quality Control and Leak Test Methods, the ISO version deleted these sections and intends to cover these items in separate documents.

This revised American National Standard is accompanied by sections in the appendixes on Quality Control and Leak Test Methods. The Quality Control section has been expanded to provide a more definitive guide so that production run sources will have performance characteristics equal to the fully tested prototype sources. The Leak Test Methods section has been up-dated to reflect current methods of leak testing.

During the period when this standard was being revised, other groups developed standards for brachytherapy sources and self-luminous sources. An attempt was made to merge these two standards, along with the IAEA tests for special form, into this classification standard. This attempt was not successful but, in order to make this standard more useful, the standards for brachytherapy sources, self-luminous sources, and the special form tests are summarized in appendixes. 
The American National Standards Committee, N43, on Equipment for Non-Medical Radiation Applications, which processed and approved this standard had the following personnel at the time it approved this revised standard:

\section{Elmer H. Eisenhower, Chairman \\ (National Bureau of Standards)}

Organization Represented

Name of Representative

Air Transport Association .................Warren J. Weldon

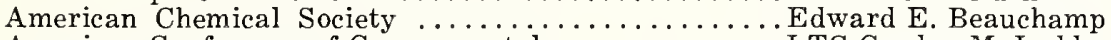

American Conference of Governmental $\cdots \cdots \cdots \cdots$ LTC Gordon M. Lodde

Industrial Hygienists.

American Crystallographic Association ........... Stanley Block

American Federation of Labor and Congress Jack R. Suarez

of Industrial Organizations.

American Insurance Association ................. John G. Pack

American Iron and Steel Institute ............. Anthony LaMastra

Wayne T. Brooks (Alt.)

American Mutual Insurance Alliance ............. Leon D. Horowitz

Thomas F. Bresnahan (Alt.)

American Nuclear Society vacant

American Public Health Association, Inc.

W. E. Kreger (Alt.)

Francis J. Bradley

Jesse Lieberman (Alt.)

American Society of Mechanical Engineers

Herbert R. Isenburger

American Society for Nondestructive Testing, Inc. .....John P. Battema

Warren M. Holm (Alt.)

American Society for Testing and Materials

Marvin M. Turkanis

American Welding Society . Jack Bystrom (Alt.)

Conference of Radiation Control Program Directors . . Leonard Solon

Richard Lane (Alt.)

Health Physics Society

John H. Weiler

Robert M. Ryan (Alt.)

Institute of Electrical and Electronics Engineers, Inc. Thomas R. Kohler

Instrument Society of America ............... L. Cook, Jr.

International Association of Machinists $\cdots \cdots \cdots \cdots$ J. George Eichhorn and Aerospace Workers.

International Brotherhood of Electrical Workers ..... Paul R. Shoop

National Bureau of Standards .......................... Eisenhower

National Council on Radiation Protection Carl B. Braestrup and Measurements. E. Dale Trout (Alt.)

National Electrical Manufacturers Association ......... L. Jackson

Underwriters' Laboratories, Inc. ............................ Homa

U.S. Nuclear Regulatory Commission ............. Robert F. Barker

U.S. Department of the Air Force, Office of

LTC William D. Howell the Surgeon General.

U.S. Department of the Army, Office of the Surgeon General.

U.S. Department of Defense

LTC Owen H. Kittilstad (Alt.)

LTC Edward W. Blackburn

Col. John E. Ward (Alt.)

Satrak Der Boghosian

Charles P. Merhib (Alt.)

U.S. Department of Health, Education, and

Walter E. Gundaker

Welfare, Public Health Service.

Edwin A. Miller (Alt.)

Individual Member

John R. Dukes 
Members of the original subcommittee which produced ANSI N5.10 were:

Barrer, L.

Beauchamp, E.

(Chairman)

Brown, R.

Coleman, E.

Cook, H. L.

Dooley, $\mathrm{H}$.

Dukes, J.

Edling, D.

Ewing, R.
Ferraro, E.

Gerhart, J.

Hendrickson, J.

Hetherington, C.

Horn, L.

Howard, N.

Karp, W.

Krieger, $\mathrm{H}$.

Lonadier, $\mathrm{F}$.

Malson, H.
Milau, J.

Miller, W.

Niemeyer, R.

O'Neill, J.

Santoro, M.

Selander, C.

Smith, D.

Turkanis, M.

Walz, R.

Members of Subcommittee N43-3.3 who were active during development of this revised standard were:

\author{
Amlauer, $\mathrm{K}$. \\ Arndt, R. \\ Bell, J. \\ Cook, H. L. \\ (Chairman) \\ Dooley, $\mathrm{H}$. \\ Dukes, J. \\ Eisenhower, E. \\ Ferraro, E. \\ Gerhart, J. \\ Hanson, L. \\ Homa, L. \\ Horowitz, L. \\ Janzow, E. \\ Kotler, J.
}

\author{
LaMastra, A. \\ Landfried, C. \\ Lima, J. \\ McLellan, J \\ Ridout, E. \\ Seminoff, $T$. \\ Sererance, W. \\ Shupe, M. \\ Sims, G. \\ Smith, D. \\ Thompson, D. \\ Turkanis, $M$. \\ Tyree, $\mathrm{P}$. \\ Walz, R. \\ Weiler, J.
}




\section{Contents}

Preface

1. Scope

2. Definitions

3. Classification Designation

4. General Considerations

5. Procedure To Establish Classification and Performance Requirements 4

6. Identification

7. Testing Procedures for Table 1

Table 1-Classification of Sealed Source Performance Tests

Table 2-Classification of Radionuclides According to Radiotoxicity

Table 3-Activity Level

Table 4-Sealed Source Performance Requirements for Typical Usage

Appendix A: Leak Test Methods

Appendix B : Quality Assurance and Control

Appendix C: Summary of American National Standard N44.1-1973:

Integrity and Test Specifications for Selected Brachytherapy Sources

Appendix D: Summary of ANSI N540: Classification of Self-Luminous

Light Sources

Appendix E: IAEA Tests for Special Form Radioactive Material.

Excerpts from IAEA Safety Series No. 6-Regulations for the Safe Transport of Radioactive Materials, 1973

Revised Edition 



\title{
American National Standard \\ Sealed Radioactive Sources, Classification
}

\begin{abstract}
This standard establishes a system of classification of sealed radioactive sources based on performance specifications related to radiation safety. It provides a manufacturer of sealed sources with a series of tests for evaluating the safety of his product under specified conditions, and also assists a user of such sources to select a type which suits the intended application insofar as maintenance of source integrity is concerned. Tests are prescribed for temperature, external pressure, impact, vibration, and puncture over a range of severity. Sealed source performance requirements are identified for a variety of source applications, in terms of a specific degree of severity of each test. Appendixes are included on the subjects of leak test methods, quality assurance and control, brachytherapy sources, self-luminous light sources, and special form radioactive material.
\end{abstract}

Key words: Classification; leak test; national standard; radiation safety; radiation sources; radioactive sources; radioactivity; sealed sources; standard.

\section{Scope}

This standard establishes a system of classification of sealed radioactive sources based on performance specifications related to radiation safety. It does not consider the radiation output of the sealed source.

It provides a manufacturer of sealed radioactive sources with a set of tests to evaluate the safety of his products under specified conditions, and also to assist a user of such sources to select types which suit the application he has in mind especially where protection against radioactivity is concerned. This standard may also be of guidance to regulatory authorities.

The tests fall into several groups including, for example, exposure to abnormally high and low temperature and a variety of mechanical tests. Each test can be applied in several degrees of severity.

Although the standard classifies sealed sources by a variety of tests, it does not imply that the sealed source will maintain its integrity if used continuously at the rated classification. For example, a sealed source tested for one hour at $600{ }^{\circ} \mathrm{C}$ may, or may not, maintain its integrity if used continuously at $600{ }^{\circ} \mathrm{C}$.

Table 4 of this standard includes a list, which is not intended to be comprehensive, of typical applications of sealed radioactive sources with a suggested test schedule for each application. These schedules are minimum requirements corresponding to the applications in the usual environment. Factors to be considered for applications in specially severe environments are listed in 4.2 and 4.3 .

This standard makes no attempt to classify either the design of sources and their method of construction or their calibration in terms of the radiation emitted.

Several subjects relating to sealed sources and their testing are not treated, in detail, in this standard. These are: selected brachytherapy sources; self-luminous light sources; IAEA tests for special form radioactive material. Accordingly, to make this document more comprehensive, these subjects are summarized in Appendixes C, D, and E.

\section{Definitions}

The definitions and terms contained in this standard, or in other American National Standards referred to in this document, are not intended to embrace all legitimate meanings of the terms. They are applicable only to the subject treated in this standard.

capsule-protective envelope used for prevention of leakage of the radioactive material.

device-any piece of equipment designated to utilize a sealed source (s).

dummy source-facsimile of a sealed source of exactly the same material and construction as 
a sealed source but containing, in place of the radioactive material, a substance resembling it as closely as practicable in physical and chemical properties.

model-descriptive term or number to identify a specific sealed source design.

non-leachable-term used to convey that the radioactive material is virtually insoluble in water and is not convertible into dispersible products.

prototype source-original of a model of a sealed source which serves as a pattern for the manufacture of all sources identified by the same model designation.

prototype testing-performance testing of a new sealed source before sources of such design are put into actual use.

radiotoxicity-the toxicity attributable to the radiation emitted by a radioactive substance within the body.

sealed source-radioactive source sealed in a capsule or having a bonded cover, the capsule or cover being strong enough to prevent contact with and dispersion of the radioactive material under the conditions of use and wear for which it was designed.

source holder-mechanical support for the sealed source.

The following two terms apply to industrial radiography, gamma gauges, and irradiator sources:

source in device-sealed source which remains in the shielding during use.

unprotected source-sealed source which, for use, is removed or exposed from the shielding by mechanical or other means.

\section{Classification Designation}

The classification of a sealed source shall be designated by the code ANSI followed by two digits to indicate the year of approval of the American National Standard used to determine the classification followed by a letter and five digits.

If the classification is based on performance tests prescribed in this standard (N542-1977), the two digits preceding the letter shall be 77 .

The letter shall be either a $\mathrm{C}$ or an E. A C designates that the activity level of the sealed source does not exceed the limit established in Table 3. An E designates that the activity level of the sealed source exceeds the limit established in Table 3.

The first digit following the letter shall be the Class number which describes the performance for temperature.

The second digit following the letter shall be the Class number which describes the performance for external pressure.

The third digit following the letter shall be the Class number which describes the performance for impact.

The fourth digit following the letter shall be the Class number which describes the performance for vibration.

The fifth digit following the letter shall be the Class number which describes the performance for puncture.

Example: a typical industrial radiography source designed for use unprotected would be designated

\section{ANSI $77 \mathrm{C} 43515$}

\section{General Considerations}

\subsection{Explanation of Tables and Appendixes}

\subsubsection{Classification of Sealed Source Per-} formance Tests (Table 1). This is a list of environmental test conditions to which a sealed source may be subjected. The test classes are arranged in order of increasing severity with the possible exception of Class X, which may be any special designated test.

The classification of each source type shall be determined by actual testing of two prototype or dummy sources for each test in Table 1 , or by derivation from previous tests which demonstrate that the source would pass the test if the test were performed. 
Compliance with the tests shall be determined by the ability of the sealed source to maintain its integrity after each test is performed. Methods of testing sources for integrity after testing are set out in Appendix A.

A source with more than one encapsulation shall be deemed to have complied with a test if it can be demonstrated that at least one encapsulation has maintained its integrity after the test.

4.1.2 Classification of Radionuclides According to Radiotoxicity (Table 2). This Table, taken from a current ICRP report, classifies radionuclides into four groups according to relative radiotoxicity.

If the radionuclide is not listed in Table 2 , the source shall be considered on an individual basis by the supplier, the user, the regulatory authority, or governmental advisory agency.

4.1.3. Activity Level (Table 3). This Table establishes a maximum activity of sealed sources for each of the four radiotoxicity groups in Table 2, without further evaluation. Sources containing more than the maximum activity shall be subject to further evaluation of the specific usage and design. The activity shall be determined at the time of manufacture of the sealed source.

Table 3 also defines the properties of the radioactive material within the sealed source as "leachable and/or reactive" and "non-leachable and nonreactive." The physical and chemical form and the geometrical shape of the radioactive material used to determine these properties shall be the same as the physical, chemical and geometrical form of the radioactive material within the sealed source.

4.1.4 Sealed Source Performance Requirements for Typical Usage (Table 4). Table 4 is based on current practice and typical environments in which a sealed source or source-device will be used. Average environment includes normal and abnormal use (taking into account reasonable accidental risks), but does not include exposure to fire or explosion. For sealed sources normally mounted in devices, consideration was given to the additional protection afforded the sealed source by the device when the Class number for a particular usage was assigned. Thus, for all usages shown in Table
4 , the Class numbers specify the tests to which the sealed source shall be subjected, except that for the category ion generators, the complete source-device combination may be tested.

Obviously, Table 4 does not cover all source usage situations. If the particular average environment differs from the values shown, or if the source usage is not shown, the specifications of the source shall be considered on an individual basis by the supplier, the user, and the regulatory authority. The numbers shown in Table 4 refer to the Class numbers used in Table 1.

4.1.5 Leak Test Methods (Appendix A). Appendix A lists currently acceptable leak test (integrity test) methods.

4.1.6 Quality Assurance and Control (Appendix B). To assure that production sources will have performance characteristics equal to the tested prototypes used in classifying the sources, a good Quality Assurance and Control program is necessary. Appendix B is included as a guide to aid a manufacturer in establishing a specific program.

\subsubsection{Summary of ANSI N44.1-1973. Integ-} rity and Test Specifications for Selected Brachytherapy Sources (Appendix C).

4.1.8 Summary of ANSI N540-1975. Classification of Self-Luminous Light Sources (Appendix D).

4.1.9 IAEA Tests for Special Form Radioactive Material. Excerpts from IAEA Safety Series No. 6-Regulations for the Safe Transport of Radioactive Materials, 1973 Revised Edition (Appendix E).

4.2 Fire, Explosion or Corrosion. Table 4 does not consider exposure of the source-device to fire, explosion or corrosion. In the evaluation of sealed sources and source-device combinations, the manufacturer and user must consider the probability of fire, explosion and corrosion and the possible results. Factors which should be considered in determining the need for actual testing are:

(1) consequence of loss of activity;

(2) quantity of active material contained in the source;

(3) radiotoxicity; 
(4) chemical and physical form and the geometrical shape of the radioactive material;

(5) environment in which it is used; and

(6) protection afforded the source or sourcedevice combination.

4.3 Radiotoxicity and Solubility. Except as required in Section 4.2 radiotoxicity of the radionuclide shall be considered only when the activity of the sealed source exceeds the value shown in Table 3. If the activity exceeds this value, the specifications of the source must be considered on an individual basis. If the activity does not exceed the values shown in Table 3, Table 4 may be used without further consideration of either radiotoxicity or solubility.

\section{Procedure To Establish Classification and Performance Requirements}

5.1. Establish radiotoxicity group from Table 2.

5.2 Determine amount of activity allowable from Table 3.

5.3 If the desired quantity does not exceed the allowable quantity of Table 3 , an evaluation of fire, explosion, and corrosion probabilities shall be made. If no significant probability with respect to fire, explosion, and corrosion exists, the required classification for the source (performance requirements) may be taken directly from Table 4 . If a significant probability does exist, the factors listed in 4.2 shall be evaluated with particular attention to the temperature and impact requirements.

5.4 If the desired quantity exceeds the allowable quantity of Table 3, an evaluation of fire, explosion or corrosion probability and a separate evaluation of the specific source usage and source design shall be made.

5.5 After the required classification of the source for the particular application or usage has been established, the performance test conditions can be obtained directly from Table 1 .

5.6 Alternatively, the source may be tested, the source Class determined from Table 1, and some suitable application selected from Table 4 . Sources of an established classification may be used in any application having less severe spe- cific performance requirements (classification numbers).

\section{Identification}

The designation according to section 3 shall be marked on the sealed source or source container or source holder or accompanying document.

\section{Testing Procedures for Table 1}

7.1 General. The testing procedures given in this section present acceptable procedures for determining performance classification numbers. All the test environments provide the minimum requirements. Procedures which can be demonstrated to be at least equivalent are also acceptable. All tests, except the temperature tests, shall be carried out at ambient temperature.

\subsection{Temperature Test ${ }^{1}$}

7.2.1 Equipment. The heating or cooling equipment shall have a test zone volume of at least five times the volume of the test specimen. If a gas or oil-fired furnace is used for the temperature test, an oxidizing atmosphere shall be maintained throughout the test.

7.2.2 Procedure. All tests shall be performed in air except in the low temperature test, when an atmosphere of carbon dioxide is permitted. All test sources shall be held at the maximum (or minimum, for low temperature tests) test temperature for a period of at least $1 \mathrm{~h}$.

Although Table 1 specifies a low temperature of $-40^{\circ} \mathrm{C}$, "dry ice" may be used as the cooling material. Thus, the low temperature may approach $-75^{\circ} \mathrm{C}$.

Sources to be subjected to temperatures below ambient shall be cooled to the test temperature in less than 45 minutes.

Sources to be subjected to temperature above ambient shall be heated to the test temperature at least as rapidly as indicated by the following time-temperature table.

\footnotetext{
${ }^{1}$ Part of this test for Class 6 is similar in principle to the heating test given in IAEA regulations for the safe transport of radioactive materials.
} 


\begin{tabular}{c|c}
\hline Time & Temperature \\
\hline $\min$ & ${ }^{\circ} \mathrm{C}$ \\
\hline 0 & ambient \\
5 & 100 \\
10 & 220 \\
30 & 450 \\
60 & 750 \\
120 & 1010 \\
\hline
\end{tabular}

For Classes 4, 5 and 6, test sources shall also be subjected to a thermal shock test. Either a second test source or the source used in the temperature test may be used. If the latter is used, it shall be evaluated for passage of the temperature test before it is subjected to the thermal shock test.

For the thermal shock test, the source shall be heated to the maximum test temperature (required for that particular Class) and held at that temperature for at least 15 minutes. The test source shall be transferred, in 15 seconds or less, to water at a maximum temperature of $20^{\circ} \mathrm{C}$. The water shall be flowing at a rate of at least ten times the source volume per minute, or, if the water is stationary, it shall have a volume of at least twenty times the source volume.

7.2.3 Evaluation. Test sources shall be examined visually and subjected to an appropriate integrity test such as that described in Appendix A.

\subsection{External Pressure Test}

7.3.1 Equipment. The pressure gauge shall have been recently calibrated and should have a pressure range of at least $10 \%$ greater than the test pressure. The vacuum gauge must read to a pressure at least as low as $20 \mathrm{kN} / \mathrm{m}^{2}$ absolute. Different test chambers may be used for the low and high pressure tests.

7.3.2 Procedure. Place the test source in the chamber and expose it to the test pressure for two periods of 5 minutes each. Return the pressure to atmospheric between each period. Conduct the low pressure test in air. For the high pressure test only water shall be used.

7.3.3 Evaluation. Test sources shall be examined visually and subjected to an appropriate integrity test such as that described in Appen$\operatorname{dix} \mathrm{A}$.

\subsection{Impact Test 2}

\subsubsection{Equipment}

This comprises :

(1) A free falling steel hammer which has a flat striking surface, $25 \mathrm{~mm}$ in diameter with the edge rounded to a radius of $3 \mathrm{~mm}$. The center of gravity of the hammer lies on the axis of the circle which defines the striking surface.

(2) A steel anvil, the mass of which is at least ten times that of the hammer. It is rigidly mounted so that it does not deflect during impact. It has a flat surface, large enough to take the whole of the source.

(3) For the Class 2 drop test, the steel plate shall be rigidly mounted so that it will not deflect appreciably during the test.

7.4.2 Procedure. Choose the mass of the hammer according to the mass specified in Table 1.

Adjust the drop height to $1 \mathrm{~m}$ measured between the top of the source positioned on the anvil and the base of the hammer in the release position.

Position the source so that it offers its most vulnerable area to the hammer.

Drop the hammer onto the source.

7.4.3 Drop Test. For the Class 2 drop test, the test sources shall be dropped so that all surfaces are impacted at least once.

7.4.4 Evaluation. Test sources shall be examined visually and subjected to an appropriate integrity test such as that described in Appen$\operatorname{dix} \mathrm{A}$.

\subsection{Vibration Test}

7.5.1 Equipment. A vibrating machine capable of producing the specified test conditions.

7.5.2 Procedure. Fix the source securely to the platform of the vibrating machine so that at all times the source will be rigidly in contact with the platform.

For Classes 2 and 3, subject the source to the three complete test cycles for each condition specified. Conduct the test by sweeping through all the frequencies in the range at a uniform rate from the minimum frequency to the maxi-

${ }^{2}$ This test is similar in principle to the percussion test given in IAEA regulations for the safe transport of radioactive materials. 
mum frequency and return to the minimum frequency in 10 minutes, or longer. Test each axis ${ }^{3}$ of the source. A maximum of three axes shall be used. In addition, continue the test for 30 minutes at each resonance frequency found.

For Class 4, subject the source to three complete test cycles for each condition specified. Conduct the test by sweeping through all the frequencies in the range at a uniform rate from the minimum frequency and return to the minimum frequency in 30 minutes, or longer. Test each axis ${ }^{3}$ of the source. A maximum of three axes shall be used. In addition, continue the test for 30 minutes at each resonance frequency found.

7.5.3 Evaluation. Test sources shall be examined visually and subjected to an appropriate integrity test such as described in Appendix A.

\subsection{Puncture Test}

\subsubsection{Equipment}

This comprises :

(1) A hammer, the upper part of which is equipped with means of attachment and the lower part of which has a pin rigidly fixed to the hammer. The characteristics of this pin are as follows:

${ }^{3} \mathrm{~A}$ spherical source has one axis taken at random. A source with an oval or disc type cross-section has two axes; one of revolution and one taken at random in a plane perpendicular to the axis of revolution. Other sources have three axes taken parallel to the significant overall dimensions. (a) hardness from 50 to 60 Rockwell C;

(b) free height $6 \mathrm{~mm}$;

(c) diameter $3 \mathrm{~mm}$;

(d) lower surface hemispherical.

The center line of the pin is in alignment with the center of gravity and with the point of attachment of the hammer.

(2) A hardened steel anvil, rigidly mounted and with a mass at least ten times that of the hammer. The contact surface between the source and the anvil is large enough to prevent deformation of this surface when impact takes place. If necessary, a cradle of suitable form may be interposed between the source and the anvil.

7.6.2 Procedure. Choose the mass of the hammer and pin according to the Class as required in Table 1.

Adjust the drop height to $1 \mathrm{~m}$ measured between the top of the source positioned on the anvil and the point of the pin in the release position.

Position the source so that it offers its most vulnerable area to the pin.

Drop the hammer onto the source.

If the source has more than one vulnerable area, carry out the test on each of them.

If the dimensions and mass of the source concerned do not permit unguided fall, lead the striker to the impact point in a smooth vertical tube.

7.6.3 Evaluation. The test sources shall be examined visually and subjected to an appropriate integrity test such as that described in Appendix A. 


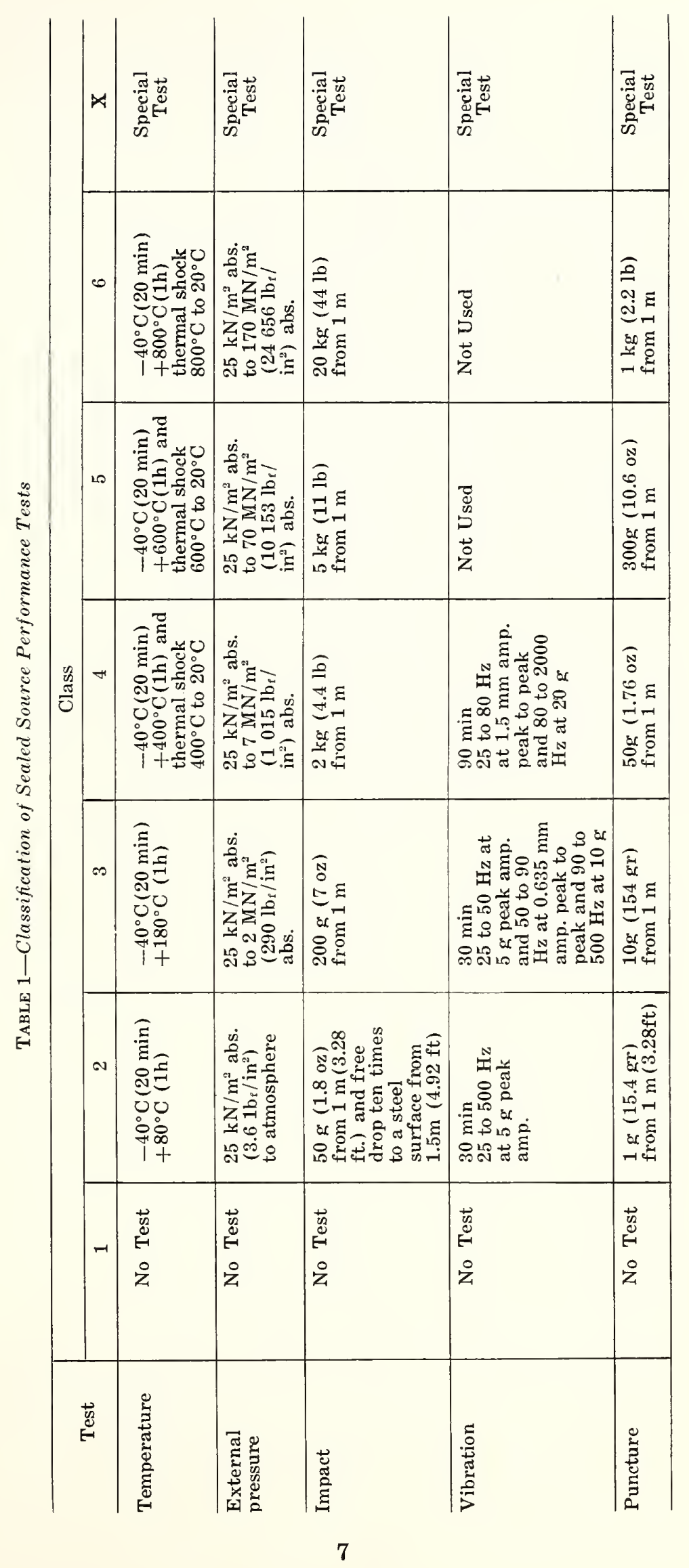


TABLE 2-Classificntion of Radionuclides According to Radiotoxicity

(Based on ICRP Publication 5)

\begin{tabular}{|c|c|c|c|c|}
\hline \multicolumn{5}{|c|}{$\begin{array}{l}\text { High Toxicity } \\
\text { Group A }\end{array}$} \\
\hline $\begin{array}{l}{ }^{227} \mathrm{Ac} \\
{ }^{241} \mathrm{Am} \\
{ }^{243} \mathrm{Am} \\
{ }^{249} \mathrm{Cf} \\
{ }^{250} \mathrm{Cf} \\
{ }^{252} \mathrm{Cf}\end{array}$ & $\begin{array}{l}{ }^{240} \mathrm{Cm} \\
{ }^{243} \mathrm{Cm} \\
{ }^{244} \mathrm{Cm} \\
{ }^{215} \mathrm{Cm} \\
{ }^{216} \mathrm{Cm} \\
{ }^{237} \mathrm{~Np}\end{array}$ & $\begin{array}{l}{ }^{231} \mathrm{~Pa} \\
{ }^{210} \mathrm{~Pb} \\
{ }^{910} \mathrm{Po} \\
{ }^{238} \mathrm{Pu} \\
{ }^{239} \mathrm{Pu} \\
{ }^{249} \mathrm{Pu}\end{array}$ & $\begin{array}{l}{ }^{241} \mathrm{Pu} \\
{ }_{442}^{42} \mathrm{Pu} \\
{ }_{223} \mathrm{Ra} \\
{ }^{233} \mathrm{Ra} \\
{ }^{225} \mathrm{Ra} \\
{ }_{294} \mathrm{Th}\end{array}$ & $\begin{array}{l}{ }^{2288} \mathrm{Th} \\
{ }^{230} \mathrm{Th} \\
{ }^{230} \mathrm{U} \\
{ }^{232} \mathrm{U} \\
{ }^{233} \mathrm{U} \\
{ }^{234} \mathrm{U}\end{array}$ \\
\hline \multicolumn{5}{|c|}{$\begin{array}{c}\text { Medium Toxicity } \\
\text { Group B-1 }\end{array}$} \\
\hline $\begin{array}{l}{ }^{228} \mathrm{Ac} \\
{ }^{119 m} \mathrm{Ag} \\
{ }^{111} \mathrm{At} \\
{ }^{140} \mathrm{Ba} \\
{ }^{207} \mathrm{Bi} \\
{ }^{196} \mathrm{Bi} \\
{ }^{249} \mathrm{Bk} \\
{ }^{45} \mathrm{Ca} \\
{ }^{115 \mathrm{~m}} \mathrm{Cd}\end{array}$ & $\begin{array}{l}{ }^{144} \mathrm{Ce} \\
{ }^{3 \theta} \mathrm{Cl} \\
{ }^{58} \mathrm{Co} \\
{ }^{60} \mathrm{Co} \\
{ }^{134} \mathrm{Cs} \\
{ }^{137} \mathrm{Cs} \\
{ }^{152(1 p y)} \mathrm{Eu} \\
{ }^{164} \mathrm{Eu} \\
{ }^{181} \mathrm{Hf}\end{array}$ & $\begin{array}{l}{ }_{124}^{12} \mathrm{I} \\
{ }^{125} \mathrm{I} \\
{ }^{133} \mathrm{I} \\
{ }^{131} \mathrm{I} \\
{ }_{133} \mathrm{I} \\
{ }^{114 \mathrm{~m}} \mathrm{In} \\
{ }^{192} \mathrm{Ir} \\
{ }^{5 \pm} \mathrm{Mn} \\
{ }_{22}^{22} \mathrm{Na} \\
{ }^{200} \mathrm{~Pa}\end{array}$ & $\begin{array}{l}{ }^{{ }^{22}} \mathrm{~Pb} \\
{ }^{224} \mathrm{Ra} \\
{ }^{108} \mathrm{Ru} \\
{ }^{124} \mathrm{Sb} \\
{ }^{125} \mathrm{Sb} \\
{ }^{48} \mathrm{Sc} \\
{ }^{80} \mathrm{Sr} \\
{ }^{100} \mathrm{Sr} \\
{ }^{182} \mathrm{Ta}\end{array}$ & 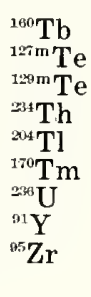 \\
\hline
\end{tabular}

Medium Toxicity

Group B-2

\begin{tabular}{|c|c|c|c|c|}
\hline $\begin{array}{l}{ }^{41} \mathrm{Ar} \\
{ }^{105} \mathrm{Ag} \\
{ }^{111} \mathrm{Ag} \\
{ }^{73} \mathrm{As} \\
{ }^{74} \mathrm{As} \\
{ }^{76} \mathrm{As} \\
{ }^{77} \mathrm{As} \\
{ }^{196} \mathrm{Au} \\
{ }^{108} \mathrm{Au} \\
{ }^{109} \mathrm{Au} \\
{ }^{131} \mathrm{Ba} \\
{ }^{7} \mathrm{Be} \\
{ }^{206} \mathrm{Bi} \\
{ }^{212} \mathrm{Bi} \\
{ }^{82} \mathrm{Br} \\
{ }^{14} \mathrm{C} \\
{ }^{47} \mathrm{Ca} \\
{ }^{109} \mathrm{Cd} \\
{ }^{115} \mathrm{Cd} \\
{ }^{141} \mathrm{Ce} \\
{ }^{143} \mathrm{Ce} \\
{ }^{38} \mathrm{Cl} \\
{ }^{58} \mathrm{Co} \\
{ }^{51} \mathrm{Co} \\
{ }^{131} \mathrm{Cr} \\
{ }^{136} \mathrm{Cs}\end{array}$ & $\begin{array}{l}{ }^{84} \mathrm{Cu} \\
{ }^{165} \mathrm{Dy} \\
{ }^{166} \mathrm{Dy} \\
{ }^{169} \mathrm{Er} \\
{ }^{171} \mathrm{Er} \\
{ }^{152(9.2 \mathrm{~h})} \mathrm{Eu} \\
{ }^{155} \mathrm{Eu} \\
{ }^{18} \mathrm{~F} \\
{ }^{52} \mathrm{Fe} \\
{ }^{55} \mathrm{Fe} \\
{ }^{56} \mathrm{Fe} \\
{ }^{67} \mathrm{Ga} \\
{ }^{72} \mathrm{Ga} \\
{ }^{153} \mathrm{Gd} \\
{ }^{159} \mathrm{Gd} \\
{ }^{197} \mathrm{Hg} \\
{ }^{107} \mathrm{Hg} \\
{ }^{203} \mathrm{Hg} \\
{ }^{160} \mathrm{Ho} \\
{ }^{130} \mathrm{I} \\
{ }^{132} \mathrm{I} \\
{ }^{134} \mathrm{I} \\
{ }^{135} \mathrm{I} \\
{ }^{115 m} \mathrm{In} \\
{ }^{190} \mathrm{Ir} \\
{ }^{101} \mathrm{Ir} \\
{ }^{42} \mathrm{~K}\end{array}$ & $\begin{array}{l}{ }^{13} \mathrm{~K} \\
{ }^{85 \mathrm{~m}} \mathrm{Kr} \\
{ }^{87} \mathrm{Kr} \\
{ }^{140} \mathrm{La} \\
{ }^{17} \mathrm{Lu} \\
{ }^{52} \mathrm{Mn} \\
{ }^{89} \mathrm{Mo} \\
{ }^{56} \mathrm{Mn} \\
{ }^{21} \mathrm{Na} \\
{ }^{83 \mathrm{~m}} \mathrm{Nb} \\
{ }^{95} \mathrm{Nb} \\
{ }^{147} \mathrm{Nd} \\
{ }^{149} \mathrm{Nd} \\
{ }^{63} \mathrm{Ni} \\
{ }^{65} \mathrm{Ni} \\
{ }^{239} \mathrm{~Np} \\
{ }^{185} \mathrm{Os} \\
{ }^{191} \mathrm{Os} \\
{ }^{193} \mathrm{Os} \\
{ }^{32} \mathrm{P} \\
{ }^{233} \mathrm{~Pa} \\
{ }^{203} \mathrm{~Pb} \\
{ }^{193} \mathrm{Pd} \\
{ }^{109} \mathrm{Pd} \\
{ }^{147} \mathrm{Pm} \\
{ }^{149} \mathrm{Pm} \\
{ }^{142} \mathrm{Pr}\end{array}$ & $\begin{array}{l}{ }^{143} \mathrm{Pr} \\
{ }^{191} \mathrm{Pt} \\
{ }^{103} \mathrm{Pt} \\
{ }^{197} \mathrm{Pt} \\
{ }^{80} \mathrm{Rb} \\
{ }^{183} \mathrm{Re} \\
{ }^{156} \mathrm{Re} \\
{ }^{188} \mathrm{Re} \\
{ }^{105} \mathrm{Rh} \\
{ }^{200} \mathrm{Rn} \\
{ }^{222} \mathrm{Rn} \\
{ }^{97} \mathrm{Ru} \\
{ }^{103} \mathrm{Ru} \\
{ }^{105} \mathrm{Ru} \\
{ }^{35} \mathrm{~S} \\
{ }^{122} \mathrm{Sb} \\
{ }^{17} \mathrm{Sc} \\
{ }^{18} \mathrm{Sc} \\
{ }^{75} \mathrm{Se} \\
{ }^{31} \mathrm{Si} \\
{ }^{15} \mathrm{Sm} \\
{ }^{153} \mathrm{Sn} \\
{ }^{113} \mathrm{Sn} \\
{ }^{125} \mathrm{Sn} \\
{ }^{85} \mathrm{Sr} \\
{ }^{91} \mathrm{Sr}\end{array}$ & 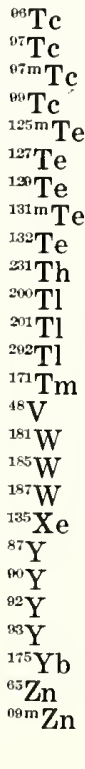 \\
\hline
\end{tabular}

Low Toxicity

Group C

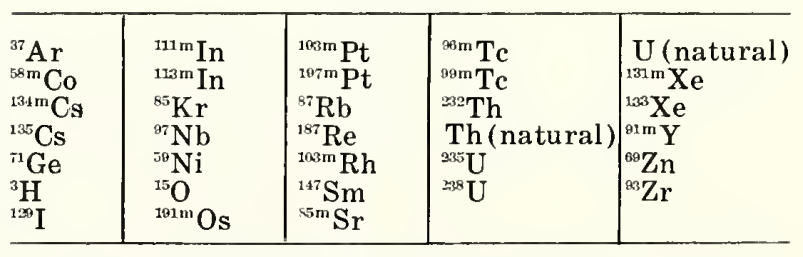

* g0 Sr has been je-allocated from Group A to Group B1 in accordance with the recommendations of ICRP Publications 5 and 6. 
TABLE 3-Activity Level

\begin{tabular}{c|c|c}
\hline \multirow{2}{*}{$\begin{array}{c}\text { Radionuclide group } \\
\text { (from Table 2) }\end{array}$} & \multicolumn{2}{|c}{ Maximum activity, Ci } \\
\cline { 2 - 3 } & $\begin{array}{c}\text { Leachable } \\
\text { and/or reactive }\end{array}$ & $\begin{array}{c}\text { Non-leachable } \\
\text { and non-reactive }\end{array}$ \\
\hline A & 0.3 & 3 \\
B1 & 30 & 300 \\
B2 & 300 & 3000 \\
C & 500 & 5000 \\
\hline
\end{tabular}

Leachable-greater than 0.1 milligram per $\mathrm{gram}$ in $100 \mathrm{ml}$ still $\mathrm{H}_{2} \mathrm{O}$ at $20^{\circ} \mathrm{C}$ in $48 \mathrm{~h}$.

5 Non-leachable- less than 0.1 milligram per gram in $100 \mathrm{ml}$ still $\mathrm{H}_{2} \mathrm{O}$ at $20^{\circ} \mathrm{C}$ in $48 \mathrm{~h}$.

Reactive-reactive in ordinary atmosphere or water ( $\mathrm{Na}, \mathrm{K}, \mathrm{U}, \mathrm{Cs}$, metals, etc.).

"Non-reactive in ordinary atmosphere or water (Al, Au, Co, Kr, Ceramics, etc.).

Note-In the expression "milligram per gram" the "milligram" refer's to th? dissolved or lemoved radionuclide, and the "gram" to the total weight of radioactive material present, not including the weight of the capsule.

TABLE 4-Sealed Source Performance Requirements for Typical Usage

\begin{tabular}{|c|c|c|c|c|c|c|}
\hline \multirow{2}{*}{ Sealed Source Usage } & & \multicolumn{5}{|c|}{ Sealed Source Test and Class } \\
\hline & & \multirow{2}{*}{\begin{tabular}{|c|}
$\begin{array}{c}\text { Tempera- } \\
\text { ture }\end{array}$ \\
4 \\
4
\end{tabular}} & \multirow{2}{*}{$\begin{array}{c}\begin{array}{c}\text { Pres- } \\
\text { sure }\end{array} \\
3 \\
3\end{array}$} & \multirow{2}{*}{$\begin{array}{c}\text { Impact } \\
5 \\
3\end{array}$} & \multirow{2}{*}{$\begin{array}{c}\begin{array}{c}\text { Vibra- } \\
\text { tion }\end{array} \\
1 \\
1\end{array}$} & \multirow{2}{*}{$\begin{array}{c}\begin{array}{c}\text { Punc- } \\
\text { ture }\end{array} \\
5 \\
3\end{array}$} \\
\hline Radiography-Industrial & $\begin{array}{l}\text { Unprotected source } \\
\text { Source in device }\end{array}$ & & & & & \\
\hline Medical & $\begin{array}{l}\text { Radiography } \\
\text { Gamma teletherapy }\end{array}$ & $\begin{array}{l}3 \\
5\end{array}$ & 2 & $\begin{array}{l}3 \\
5 \\
5\end{array}$ & $\begin{array}{l}1 \\
2\end{array}$ & $\begin{array}{l}2 \\
4\end{array}$ \\
\hline $\begin{array}{l}\text { Gamma gauges (medium and } \\
\text { high energy) }\end{array}$ & $\begin{array}{l}\text { Unprotected source } \\
\text { Source in device }\end{array}$ & $\begin{array}{l}4 \\
4\end{array}$ & $\begin{array}{l}3 \\
3\end{array}$ & $\begin{array}{l}3 \\
2\end{array}$ & $\begin{array}{l}3 \\
3\end{array}$ & $\begin{array}{l}3 \\
3\end{array}$ \\
\hline \multicolumn{2}{|c|}{$\begin{array}{l}\text { Beta gauges and sources for low energy gamma gauges } \\
\text { or X-Ray fluorescence analysis (excluding gas filled } \\
\text { sources) }\end{array}$} & 3 & 3 & 2 & 2 & 2 \\
\hline \multicolumn{2}{|l|}{ Oil Well logging } & 5 & 6 & 5 & 2 & 2 \\
\hline \multicolumn{2}{|c|}{$\begin{array}{l}\text { Portable moisture and density gauge (including hand held } \\
\text { or dolly transported) }\end{array}$} & 4 & 3 & 3 & 3 & 3 \\
\hline \multicolumn{2}{|c|}{$\begin{array}{l}\text { General neutron source application (excluding reactor } \\
\text { start-up) }\end{array}$} & 4 & 3 & 3 & 2 & 3 \\
\hline \multicolumn{2}{|c|}{ Calibration sources-Activity greater than $30 \mu \mathrm{Ci}$} & 2 & 2 & 2 & 1 & 2 \\
\hline Gamma Irradiators" & $\begin{array}{l}\text { Categories II, III, IV } \\
\text { Category I }\end{array}$ & $\begin{array}{l}4 \\
4\end{array}$ & $\begin{array}{l}3 \\
3\end{array}$ & $\begin{array}{l}4 \\
3\end{array}$ & $\begin{array}{l}2 \\
2\end{array}$ & $\begin{array}{l}4 \\
3\end{array}$ \\
\hline Ion generators ${ }^{s}$ & $\begin{array}{l}\text { Chromatography } \\
\text { Static Eliminators } \\
\text { Smoke Detectors }\end{array}$ & $\begin{array}{l}3 \\
2 \\
3\end{array}$ & $\begin{array}{l}2 \\
2 \\
2\end{array}$ & $\begin{array}{l}2 \\
2 \\
2\end{array}$ & $\begin{array}{l}1 \\
2 \\
2\end{array}$ & $\begin{array}{l}1 \\
2 \\
2\end{array}$ \\
\hline
\end{tabular}

8 Source-device combination may be tested.

- For the purposes of this Standard, gamma irradiator's have been divided into four distinct categories.

Category I - Self-Contained-Dry Source Storage.

Category II - Panoramic-Dry Source Storage.

Category III-Self-Contained-Wet Source Storage.

Category IV-Panoramic-Wet Source Storage. 


\section{Appendix A. Leak Test Methods}

(This Appendix is not a part of American National Standard N542, Sealed Radioactive Sources, Classification. It is included for informative purposes and as a guide to promote uniformity of practice to meet the objectives of the standard.)

\section{A1. General}

Maintenance of its integrity after testing of the sealed source is the criterion for determining that a source meets the specifications of a particular class for a given test. Testing for the presence of radioactive material on the exterior of a sealed source, after it has been subjected to a test, is a method of determining whether the source has fulfilled the requirements of the test or has failed the test.

Even though testing for the presence of radioactive material on the exterior of a sealed source is mandatory for the production sources, it is not always the best test to use for prototype sources when the specifications of a particular configuration are being determined.

In the case of any test that depends on the measurement of radioactive material associated with a test source as an indicator of source capsule integrity, a comparison of activity removed from the source before and after a performance test must be the criterion. The amount of activity removed from a source following a performance test, unless related to the removable activity on the source before the test, is not a measure of leakage from the test source interior or necessarily an indication of a breach in capsule integrity.

Several methods of leak testing (integrity testing) are acceptable to determine whether a sealed source meets or fails the specifications of a test. Not all the listed leak-test methods are applicable to all sources. The test, or tests, most applicable to a particular source configuration should be chosen.

In the case of multiple encapsulations, different leak-test methods may be appropriate for each encapsulation.

In general, sealed sources which have an internal void volume of less than $0.10 \mathrm{~mL}$ should be tested by one or more of the following tests:
Wipe (Smear) Test, as in A2.1.1

Dry Wipe Test, as in A2.1.2

Immersion with Boiling Test, as in A2.1.3

Sealed sources which have an internal void volume greater than $0.10 \mathrm{~mL}$ may be tested using any of the methods described in section A.2. of this Appendix.

The internal void volume includes all void space within the outer sealed enclosure. When porous compounds are substituted for the radioactive material, the void space in the porous compound constitutes a part of the total void volume. For doubly encapsulated sources, the total void volume includes the void space between the inner and outer capsules.

Visual examination of source surfaces and weldments at magnifications from 2 to $20 \times$ is a useful supplement to the leak test methods described in section A2. Visual examination alone will not prove the presence or absence of leaks but it may reveal porosity capable of retaining radioactive materials in sufficient quantities that a source will not pass tests A2.1.1 or A2.1.2., yet is found not to leak.

\section{A2. Acceptable Leak Test Methods}

A2.1. By Radioactive Means. For the tests by radioactive means, it is assumed that the source has been cleaned and is free from radioactive surface contamination before the performance test is initiated.

A2.1:1. Wipe (Smear) Test. Wipe all external surfaces of the sealed source thoroughly with a piece of filter paper or other suitable material of high wet strength and absorbent capacity, moistened with a solvent which will not attack the material of which the outer surfaces of the source are made and which, under con- 
ditions of this test, has been demonstrated to be effective in removing the radioactive substance involved. Measure the activity on the wiping material. If the activity is less than 5 $\mathrm{nCi}$ the source is considered to be leak free.

A2.1.2. Dry Wipe Test. Wipe all external surfaces of the source thoroughly with a piece of dry filter paper. Measure the activity on the filter paper. If the activity is less than $5 \mathrm{nCi}$, the source is considered to be leak free.

A2.1.3. Immersion with Boiling Test. Immerse the sealed source in a solvent which will not attack the material of which the outer surfaces of the source are made and which, under the conditions of this test, has been demonstrated to be effective in removing the radionuclide involved. Boil for 10 minutes, remove the source (retaining the solvent) and allow to cool, then rinse the source using fresh solvent. Repeat these operations twice, for a total of three tests, using the original solvent for the boiling. Measure the total activity in the solvent. If the activity is less than $5 \mathrm{nCi}$ the source is considered. leak free.

A2.1.4. Gaseous Emanation Test (for Radium-226 Sources). Put the sealed source to be tested into an appropriate small gas-tight container together with activated carbon or two cotton filters and leave it there for 24 hours. Take out the source and shut the container again. Measure immediately the activity of the absorber. If the activity corresponds to less than $1 \mathrm{nCi}$ of Radon or daughter products, the source is considered leak free.

A2.1.5. Kr-85 Test. Place the cleaned sealed source in a suitable pressure chamber. Evacuate the chamber and introduce a known amount of $\mathrm{Kr}-85$. Pressurize the chamber with argon to a pressure of at least $0.4 \mathrm{MN} / \mathrm{m}^{2}\left(60 \mathrm{lb}_{\mathrm{f}} / \mathrm{in}^{2}\right)$ for at least 10 minutes. Vent the chamber and place the source in a clean test chamber. Purge the chamber with argon at atmospheric pressure and allow the system to stand for at least 5 minutes. Draw a fraction of the chamber atmosphere into an evacuated, calibrated $\mathrm{Kr}-85$ counting chamber. Calculate the leak rate from the counting rate. If the leak rate is less than $1 \times 10^{-8}$ standard cubic centimeter per second, the source is considered leak free.
A2.2. By Non-Radioactive Means. Note: Before any of these tests, the source should be cleaned thoroughly.

A2.2.1. Vacuum Bubble Test. ${ }^{1}$ Using analytical reagent grade ethylene glycol, water or silicon oil ${ }^{2}$ as the leak test fluid in a suitable vacuum chamber, lower the air content of the fluid by evacuating the chamber for at least 1 minute and then return to atmospheric pressure. Submerge the source capsule completely to a depth of at least $5 \mathrm{~cm}$ ( 2 in) below the fluid level. Reduce the pressure in the chamber to between 15 and $25 \mathrm{kN} / \mathrm{m}^{2}$ ( 2 and 3.6 $\mathrm{lb}_{\mathrm{f}} / \mathrm{in}^{2}$ ) absolute. Observe for bubble(s) over a period of 2 minutes. If none are observed the source is considered leak free.

A2.2.2. Hot Liquid Bubble Test. Insure that the sealed source is at ambient temperature. Immerse it in a water bath which is at a temperature between 90 and $95^{\circ} \mathrm{C}$. Observe for bubble leaks over a period of at least 2 minutes. If none are observed the source is considered leak free.

Note: Glycerol at 120 to $150^{\circ} \mathrm{C}$ is an acceptable alternative for water.

A2.2.3. Helium Pressurization Bubble Test. Place the sealed source in a suitable pressure chamber of volume at least twice that of the source and at least five times the free volume inside the source. Pressurize the chamber with helium gas to at least $1 \mathrm{MN} / \mathrm{m}^{2}\left(150 \mathrm{lb} / \mathrm{in}^{2}\right)$ gauge and maintain it at that pressure for 15 minutes. Release the pressure, remove the source from the chamber and submerge it below $5 \mathrm{~cm}$ of water, alcohol or acetone. Observe for bubble(s) over a period of 2 minutes. If none are observed the source is considered leak free.

A2.2.4. Pressurization Test. This test is essentially an operational consequence to the external pressure test of Classes $3,4,5$ and 6 . Weigh the source. Perform the external pressure test with water and weigh the source again. If there is no gain in weight, the source is considered leak free. For this test to be valid

\footnotetext{
I C. R. King, USAEC Rpt. ORNL-3664, Oak Ridge National Laboratory (January 1965).

Mass density at $20^{\circ} \mathrm{C}: 890 \mathrm{~kg} / \mathrm{m}^{3}$.

Kinematic viscosity at $20^{\circ} \mathrm{C}: 25$ centistokes.

Kinematic viscosity at $50^{\circ} \mathrm{C}: 9.0$ centistokes.
} 
the calculated void volume within the source has to be capable of holding water which would weigh at least five times the sensitivity of the weighing equipment.

Note: Water is the only pressurizing fluid acceptable for this test.

A2.2.5. Helium Sealing Test. Make the final seal on the sealed source in an atmosphere containing at least $\mathbf{5 \%}$ commercial grade helium. Evacuate the space around the source, let it stand for at least 5 minutes and sample the space around the source for the presence of helium, following the recommendations of the manufacturer of the leak testing equipment. If less than $1 \times 10^{-8}$ standard cubic centimeter per second of helium is detected the source is considered leak free.

\section{A2.2.6. Helium Pressurization Test.}

A2.2.6.1 Procedure. Place the sealed source in a pressure chamber. Purge the chamber of air with helium. Pressurize the chamber to at least $1 \mathrm{MN} / \mathrm{m}^{2}\left(150 \mathrm{lb}_{\mathrm{f}} / \mathrm{in}^{2}\right)$ gauge with helium and maintain for a period of 30 minutes. (Other pressures and time periods are acceptable if the through-put is equivalent.) Depressurize the chamber and remove the source assembly to a vacuum chamber. Evacuate that chamber, monitored with a leak detector, to a specified pressure, following the recommendations of the manufacturer of the leak testing equipment.

A2.2.6.2 Helium Leak Testing. Operations of the leak detector shall be strictly in accordance with the manufacturer's instructions.

The leak detector and vacuum system must be calibrated by using a calibrated leak before and after leak testing of each source capsule.

The pieces tested must be free of dirt, grease, burrs, etc., which would tend either to clog defects or to damage the pressure and vacuum fittings.

Leak testing must be performed in well-ventilated areas to minimize the possibility of detecting helium-contaminated air.

The vacuum system, exclusive of the vacuum chamber, must be kept under a continuous dynamic vacuum.

\section{A2.2.6.3 Testing of Source}

A2.2.6.3.1 Before each finished source assembly is tested, the following blank tests must be performed. Source-assembly background is to be determined by testing a solid bar of the same dimensions and material and with approximately the same configuration as the source assembly. The bar is to be subjected to the previously described pressurization before it is leak tested.

A2.2.6.3.2 Place the finished source assembly inside the vacuum chamber.

A2.2.6.3.3 Evacuate the chamber and begin monitoring when the system pressure falls within the range of the leak detector.

A2.2.6.3.4 Measure helium signal after continuous pumping with an open throttle valve for 1 minute; isolate the chamber from the vacuum pumps, accumulate any helium for 30 minutes and measure helium signal.

A2.2.6.4 Data Required. Record the magnitude of leak indication for each of the following:

a. Chamber background.

b. Solid-bar background, after 1 minute and after 30 minutes.

c. Each source after 1 minute and after 30 minutes. If $c$ is less than $b$ or equal to or less than $1 \times 10^{-8}$ standard cubic centimeter per second of helium, consider the source leak free.

A2.2.7 Liquid Nitrogen-Alcohol Bubble Test (only for sources having high decay heat). Immerse the source into a liquid nitrogen bath for a period of at least five minutes. Remove the source from the liquid nitrogen and immediately immerse in a clear (glass) vessel containing clear alcohol (isopropyl or ethylene glycol) at ambient temperature. Observe for leakage of gas from the source, with particular attention to the weld areas, for a period of at least two minutes. If none is observed the source is considered leak free. 


\section{Appendix B \\ Quality Assurance and Control}

(This appendix is not a part of American National Standard N542, Sealed Radioactive Sources, Classification. It is included for information purposes and as a guide to promote uniformity of practice to meet the objectives of the standard. It is not intended as a substitute for each manufacturer's evaluation of the applicable requirements.)

\section{B1. Introduction}

A quality assurance program or plan is essential in both the design and manufacture of sealed sources. This is not to be considered as a complete program. Each manufacturer should add to it or delete from it as may be necessary in his particular case.

\section{B1.1 Definitions}

Quality Assurance ${ }^{1}$-All those planned and systematic actions necessary to provide adequate confidence that an item or a facility will perform satisfactorily in service.

Quaity Control ${ }^{1}$ - Those quality assurance actions which provide a means to control and measure the characteristics of an item, process, or facility to established requirements.

Certificate of Compliance ${ }^{1}-\mathrm{A}$ written statement, signed by a qualified party, attesting that the items or services are in accordance with specified requirements and accompanied by additional information to substantiate the statement.

\section{B2. Intent}

The intent of this appendix is to insure that production sources meet the required standard.

To accomplish this intent, all failures (either from the field or in process) should be analyzed. If the record keeping and traceability procedures are adequate, the cause of the failures can be located and corrected. Without systematic record keeping, the cause of failure frequently cannot be determined. Hence the lesson to be learned from the failure is lost.

${ }^{1}$ ANSI N45.2.10-1973. Quality Assurance Terms and Definitions.

\section{B3. Scope}

The fabrication of sealed radioactive sources can be broken down into three separate functions, 1) preparation for assembly, 2) assembly, and 3) verification and/or certification. Each of these functions will be dealt with in detail since each function has separate and distinct approaches to quality assurance and control.

\section{B4. Preparation for Assembly}

In order to fabricate sealed sources the manufacturer should have:

Specifications and/or engineering drawings Trained personnel

Proper equipment and procedures

Approved materials

B4.1. Specifications and/or Engineering Drawings. All production sealed sources should be fabricated to specifications and/or engineering drawings. These documents should list all pertinent information such as dimensions, materials, tests required, and fabrication techniques.

All specifications and/or engineering drawings should be kept current.

B4.2. Trained Personnel. The manufacturer should be responsible to ensure that only trained and competent personnel are involved in the fabrication and testing of sealed sources.

The manufacturer should maintain pertinent records of the training given to these personnel.

B4.3. Equipment and Procedures. The manufacturer should have written operating procedures for all major production and test equipment. These procedures should include who is responsible for calibration, maintenance and repair, and when such operations are to be performed. 
B4.4. Approved Materials. All incoming parts and materials should be inspected to insure that they meet the requirements of the specifications and/or engineering drawings. Alternately, a certificate of compliance is acceptable. The manufacturer should maintain a materials control program. The records of this program should be adequate to insure traceability of all parts and materials shipped as sealed sources.

\section{B5. Assembly}

All pertinent fabrication records, or cross references to such records, should be maintained in one file for each order, lot or other systematically separate group of sealed sources. For purposes of discussion, this file of records is called a traveller.

The traveller should contain, in addition to materials control records, a work sheet(s) which lists the operations performed, quantities of materials used, equipment settings, tests performed and results for all fabrication steps. Work sheets should be signed and dated.

Inspection sheets or tests performed by quality control are to be added to the traveller. Copies of all pertinent shipping documents or cross references to them are also to be included in the traveller, which is then filed.

Each sealed source or some accompanying tag, label or certificate, should show some designation such as lot number, model number or serial number which refers to the traveller.

\section{B6. Certification}

Each sealed source, or where appropriate, sealed source lot, should be certified by the manufacturer to meet the specifications. This certification should include, at least, the following information:
Isotope and Amount

Date of Measurement

Leak Test Results

Removable Contamination Levels

Source Identification

ANSI Classification Designation

Unless otherwise specified, statistical sampling and testing may be used for large lot sizes. Such systems are described in Mil-STD105 and 10 CFR 32.110.

\section{B7. Quality Assurance Manual}

A quality assurance manual should be kept by the sealed source manufacturer. The manual should contain policies covering each facet of quality assurance or reference thereto, all test procedures, and all procedures covering personnel training, vendor qualifications, document control, and equipment operating procedures.

This manual should be audited by the manufacturer, at least once a year.

All personnel directly involved in the fabrication of sealed sources should have a copy of the manual available to them.

The quality assurance manual should have sections covering, or referring to, at least the following subjects :

a) Department and Quality Organization

b) General Quality Policy

c) Specifications and/or Engineering Drawings Control and Revision

d) Incoming Inspection and Vendor Qualification

e) Test Procedures

f) Operating Procedures

g) Personnel Training

h) Non-Conforming Items Policy

i) Document Control

j) Equipment Calibration

k) Quality Audits and Reports 


\title{
Appendix C
}

\section{Summary of American National Standard N44.1-1973: Integrity and Test Specifications for Selected Brachytherapy Sources}

\author{
(This appendix is not a part of N542, Sealed Radioactive Sources, Classification.)
}

\section{C1. General Considerations}

This summary covers, in a brief way, the scope, integrity criteria, test specifications and quality control standards appropriate for selected brachytherapy sources as developed in ANSI N44.1-1973. For a complete discussion relative to these criteria and specifications it is recommended that the entire standard be obtained and read. The integrity and test specifications of this standard are appropriate only for commonly used brachytherapy sources, specifically tubes, capsules and needles containing either Ra-226, Co-60 or Cs-137 and beta applicators containing either $\mathrm{Sr}-90$ or $\mathrm{Ra}-226$. Other types of brachytherapy sources are beyond the scope of this standard. The integrity criteria developed are specific to the use of the particular source in medical practice. Specific definitions relative to each of the three types of sources covered can be found in the standard.

\section{C2. Integrity Criteria}

For purposes of this standard a source is considered to pass the integrity test if integrity is retained as determined by visual inspection and a suitable leakage test. For purposes of this standard only, retention of integrity is defined as absence of leakage of radioactive material at a level which would be expected to be significant from a health and safety standpoint. In the case of all isotopes except $\mathrm{Ra}-226$ this is considered to be $50 \mathrm{nCi}$. In the case of Ra-226 source acceptability is indicated by a leakage rate of less than $10 \mathrm{nCi}$ of radon in 24 hours.

Integrity test requirements for each of the three classes of sources are as below.

$\begin{array}{ll}\text { Source Type } & \text { Test Required } \\ \text { Tubes (Capsules) } & \text { Temperature } \\ & \text { Impact } \\ & \text { Percussion }\end{array}$

Needles

Temperature

Impact

Percussion

Bending

Tensile Stress

Beta Applicators

Temperature

Impact

Percussion

Puncture

\section{C3. Test Specifications}

Tests are to be carried out on units identical to production units with identity or equivalence of prototypes being strictly interpreted with regard to chemical form, sealing methods, source materials, etc. However, differences in non-critical physical dimensions are allowed. For example, tests on needles need to be carried out on needles of one length only. A minimum of two prototypes or production sources shall be used for each test with the tests not being construed as being cumulative. In the event both test units fail, the source design shall be considered unacceptable. If one of the two units fails a specific test, three additional units can be tested. Unless all three of these pass the particular test the source design shall be considered unacceptable.

Test environments have been developed and are generally similar to those described for the Special Form requirements as developed in IAEA Safety Standard "Regulations for the Safe Transport of Radioactive Materials-1973 Revised Edition". Other tests are specific to the use of the sources in medical therapy. The general test specifications are as described below.

Test

Temperature

\section{Method}

$800^{\circ} \mathrm{C} \pm 2{ }^{\circ} \mathrm{C}$ for 60 minutes with thermal shock to $15^{\circ} \mathrm{C}$ in water 
Impact

Percussion

Bending

Tensile Stress

Mass of $11 \mathrm{~kg}$ suspended from eyelet end of needle. Mass to be suspended for at least 60 seconds

Puncture

\section{C4. Quality Control}

A viable quality control program is required for the design and manufacture of brachytherapy sources. This program includes appropriate design, choice of material and adequate production controls. It is the purpose of the quality-control programs especially as regards acceptance testing of production units, to insure that the production units will have the same integrity and meet the same requirements as the prototype units tested pursuant to this standard. Wherever practical, sources shall be serially identified so that traceability to test data can be implemented if required. Such acceptance testing shall include, as a minimum, visual inspection and a leakage test as included in American National Standard N44.2-1973.

\section{Appendix D \\ Summary of ANSI N540: Classification of Self-Luminous Light Sources}

(This appendix is not a part of N542, Sealed Radioactive Sources, Classification.)

\begin{abstract}
ANSI Subcommittee N43-2 has developed a standard for use in the classification of selfluminous light sources. This standard, N540, is similar to ANSI N542 (5.10-1968 revised) for classification of sealed sources in that it provides a system for classifying a product according to its ability to withstand specified tests. The classification tests and designation provisions of ANSI N540, however, differ from those in ANSI N542, and are briefly summarized below. ANSI N540 may be consulted for
\end{abstract} additional details.

ANSI N540 contains three tables. Table 1 establishes the maximum curie content of an individual self-luminous source for classification under the standard. The listed radionuclides and limits include: tritium, $5 \mathrm{Ci}$ as a painted source or $50 \mathrm{Ci}$ as a gaseous source; krypton-85, $30 \mathrm{Ci}$ as a gaseous source; and promethium-147, 0.3 $\mathrm{Ci}$ as a painted source.

Table 3 of ANSI N540 provides performance standards for classification of self-luminous light sources. To determine minimum test requirements for a self-luminous light source, e.g., a 0.4 Ci tritium gaseous source, one determines from Column 1 of Table 2 that a classification of " 2 " applies which means that the following performance test levels apply: Discoloration (level 1), Temperature (level 2), Thermal Shock (level 2), Reduced Pressure (level 2), Impact (level 2), Vibration (level 2), and Immersion (level 2).

Table 2 of ANSI N540 specifies test conditions for the respective test levels. Additional testing details such as a one hour interval for the temperature test and 4 periods of $15 \mathrm{~min}$ utes each for the reduced pressure test, are set forth in the testing procedures.

Tests are performed sequentially on 2 sources and definition of compliance with a performance test is set out in section 8 of ANSI N540. In brief, following the entire test sequence, (1) the sources must be examined visually for any evidence of failure, (2) the radioactivity in the water used for the immersion test must not exceed 1 microcurie for painted tritium sources, 50 nanocuries for gaseous tritium sources, or 5 nanocuries for other sources, (3) loss of 
luminosity shall not exceed $20 \%$, (4) wipe tests shall not show more than 1 microcurie for tritium painted sources or 5 nanocuries for other sources, (5) 24-hour water soak tests shall not show more than one microcurie for painted tritium sources, 50 nanocuries for gaseous tritium sources, or 5 nanocuries for other sources, and (6) leakage from gaseous sources other than tritium shall not exceed 5 nanocuries/24 hours.

The classification of a self-luminous light source is designated by a series of letters and digits whereby the first one or two letters designate the radionuclide, the next character indicates the classification test and is underlined for emphasis, the next character designates the type of source such as "P" for painted and " $G$ " for gaseous, the next character indi- cates whether the curie content does or does not exceed the limit in Table 1 using the letter " $E$ " if the limit is exceeded or " $C$ " if it is not. Accordingly, the proper designation for a 0.4 $\mathrm{Ci}$ tritium gas source, involving no abnormal conditions and tested in accordance with test level 2 would be "T2GC". If the same source had successfully been subjected to a more severe impact test, e.g., level 4, this information may be shown by the expanded designation "T2GC1222422".

The ANSI classification designation shall be marked on the source, its container, or its source holder. If space limitation does not permit such marking, the classification designation shall appear on accompanying documents.

TABLE 1. Maximum Activity in Curies of an Individual Self-Luminous Light Source (from ANSI N540)

\begin{tabular}{|c|c|c|c|c|}
\hline 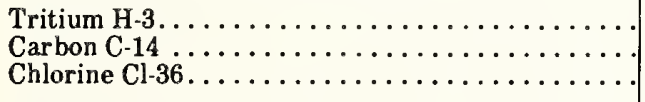 & $\begin{array}{l}1 \\
0.06 \\
.006\end{array}$ & $\begin{array}{l}5 \\
0.3 \\
.03^{b}\end{array}$ & $\begin{array}{l}5 \\
0.3 \\
.03\end{array}$ & $\begin{array}{l}50^{\circ} \\
30\left(\mathrm{CO}_{2}\right) \\
3\end{array}$ \\
\hline 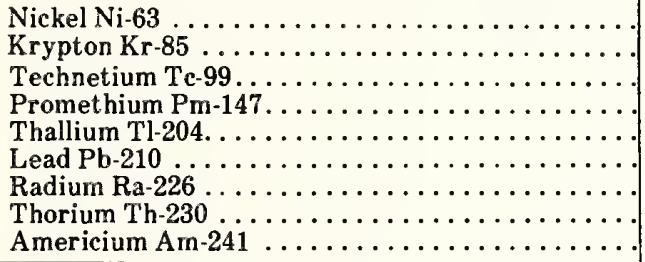 & $\begin{array}{l}.06 \\
.006^{c} \\
.06 \\
.06 \\
.006 \\
.0003 \\
.00002 \\
.00002 \\
.00002\end{array}$ & $\begin{array}{l}.3 \\
.03^{c} \\
.3 \\
.3 \\
.03 \\
.0015 \\
.0001 \\
.0001 \\
.0001\end{array}$ & $\begin{array}{l}.3 \\
.03^{c} \\
.3 \\
.3 \\
.03 \\
.0075 \\
.0005 \\
.0005 \\
.0005\end{array}$ & $\begin{array}{l}\overline{30} \\
- \\
- \\
- \\
- \\
- \\
-\end{array}$ \\
\hline
\end{tabular}

- Tritium oxide content shall not exceed the greater of (a) 1 percent of tritium in source, or (b) $1 \mathrm{mCi}$.

s Cl Salt

c Kryptonate 
TABLE 2-Self-Luminous Light Source Performance Tests (from ANSI N540)

\begin{tabular}{|c|c|c|c|c|c|}
\hline Type of Test & \multicolumn{5}{|c|}{ Test Levels } \\
\hline $\begin{array}{l}\text { Discoloration } \\
\text { Temperature } \\
\text { Thermal Shock } \\
\text { Pressure } \\
\text { (Reduced) } \\
\text { Impact }\end{array}$ & $\begin{array}{l}12 \text { hr. lamp } \\
\text { No test } \\
\text { No test } \\
\text { No test } \\
\text { No test }\end{array}$ & $\begin{array}{l}0^{\circ} \mathrm{C} \text { and } \overline{50} \\
0^{\circ} \mathrm{C} \text { to } 50^{\circ} \mathrm{C} \\
226 \mathrm{~mm} \mathrm{Hg} \text { abs. } \\
\text { Free fall to } \\
\text { steel plate } \\
1 \mathrm{~m} 2 \mathrm{x}\end{array}$ & $\begin{array}{l}-30^{\circ} \mathrm{C} \text { and } 65^{\circ} \mathrm{C} \\
-30^{\circ} \mathrm{C} \text { to } 65^{\circ} \mathrm{C} \\
175 \mathrm{~mm} \mathrm{Hg} \text { abs. } \\
\text { Free fall to } \\
\text { steel plate } \\
1 \mathrm{~m} 20 \mathrm{x}\end{array}$ & $\begin{array}{l}-55 \mathrm{C}^{\circ} \text { and } 80^{\circ} \mathrm{C} \\
-55^{\circ} \mathrm{C} \text { to } 80^{\circ} \mathrm{C} \\
87 \mathrm{~mm} \mathrm{Hg} \text { abs. } \\
\text { Free fall to } \\
\text { steel plate } \\
1 \mathrm{~m} 20 \mathrm{x} \text { and } \\
2 \mathrm{~m} 2 \mathrm{x}\end{array}$ & $\begin{array}{l}\text { Special } \\
\text { Special } \\
\text { Special } \\
\text { Special } \\
\text { Special }\end{array}$ \\
\hline Vibration & No test & \multicolumn{4}{|c|}{$\begin{array}{l}\text { Simple harmonic motion having an amplitude of } 0.075 \mathrm{~cm}\left(0.03^{\prime \prime}\right) \text { and a } \\
\text { maximum total excursion of } 0.15 \mathrm{~cm}\left(0.06^{\prime \prime}\right) \text {, the frequency being varied } \\
\text { uniformly between the approximate limits of } 10 \text { and } 55 \mathrm{Hertz}(\mathrm{Hz}) \text {. The } \\
\text { entire frequency range, between } 10 \text { and } 55 \mathrm{~Hz} \text { and return to } 10 \mathrm{~Hz} \text {, shall } \\
\text { be traversed in approximately one (1) minute. } \\
\begin{array}{l}10 \text { minutes } \\
30 \text { minutes }\end{array} \quad 60 \text { minutes } \\
\text { Special }\end{array}$} \\
\hline
\end{tabular}

Tests to be performed in the order shown.

All temperatures specified $\pm 3^{\circ} \mathrm{C}$.

TABLE 3-Performance Standards for Classification of Self-Luminous Light Sources (from ANSI N540)

\begin{tabular}{|c|c|c|c|c|c|c|c|c|c|}
\hline \multirow[b]{2}{*}{ Source Activity } & \multirow[b]{2}{*}{ Usage } & \multirow[b]{2}{*}{$\begin{array}{l}\text { Classifi- } \\
\text { cation }\end{array}$} & \multicolumn{7}{|c|}{ Performance Test Level (Table 2) } \\
\hline & & & $\begin{array}{l}\text { Dis- } \\
\text { colora- } \\
\text { tion }\end{array}$ & $\begin{array}{l}\text { Tem- } \\
\text { pera- } \\
\text { ture }\end{array}$ & $\begin{array}{c}\text { Thermal } \\
\text { Shock }\end{array}$ & $\begin{array}{c}\text { Pres- } \\
\text { sure } \\
\text { ( reduced) }\end{array}$ & $\begin{array}{l}\text { Im- } \\
\text { pact }\end{array}$ & $\begin{array}{l}\text { Vibra- } \\
\text { tion }\end{array}$ & $\underset{\text { sion }}{\text { Immer }}$ \\
\hline $\begin{array}{l}<0.1 \% \text { of } \\
\text { Table } 1\end{array}$ & any & 1 & 1 & 1 & 1 & 1 & 1 & 1 & 1 \\
\hline $\begin{array}{l}\Rightarrow 0.1 \% \text { to }<1 \% \text { of } \\
\text { Table } 1\end{array}$ & any & 2 & $\mathbf{1}^{\circ}$ & 2 & 2 & 2 & 2 & 2 & 2 \\
\hline \multirow{2}{*}{$\begin{array}{l}\geqslant 1 \% \text { to }<10 \% \text { of } \\
\text { Table } 1\end{array}$} & fixed & 3 & 1 & 3 & 3 & 3 & 2 & 2 & 2 \\
\hline & mobile & 4 & 1 & 3 & 3 & 3 & 3 & 3 & 3 \\
\hline \multirow{2}{*}{$\begin{array}{l}\Rightarrow 10 \% \text { to } \leq 100 \% \text { of } \\
\text { Table } 1\end{array}$} & fixed & 5 & 1 & 3 & 3 & 3 & 3 & 3 & 3 \\
\hline & mobile & 6 & 1 & 3 & 3 & 3 & 4 & 4 & 4 \\
\hline $\begin{array}{l}\text { Does not exceed } \\
\text { Table } 1\end{array}$ & $\begin{array}{l}\text { maximum } \\
\text { normal } \\
\text { environ- } \\
\text { ment }\end{array}$ & 7 & $1^{*}$ & $4^{*}$ & $4 *$ & $4^{*}$ & $4^{*}$ & $4^{*}$ & $4^{*}$ \\
\hline
\end{tabular}

Note: The above figures are minimum requirements for applications involving normal usage. Where special environmental conditions

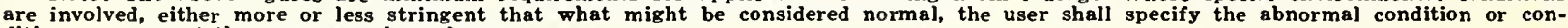
ditions, or request the necessary class change.

- Or special, as required for specific abnormal environmental condition(s). Use the digit 5 where applicable to indicate the special test $(\mathrm{s})$. 


\section{Appendix E \\ IAEA Tests for Special Form Radioactive Material \\ Excerpts from IAEA Safety Series No. 6-Regulations for the Safe Transport of Radioactive Materials, 1973 Revised Edition}

(This appendix is not a part of N542, Sealed Radioactive Sources, Classification.)

\section{General}

726. The tests are: the impact test, the percussion test, the bending test and the heat test.

727. Specimens (solid radioactive material or capsules) to be tested shall be prepared as normally presented for transport. The radioactive material shall be duplicated as closely as practicable.

728. A different specimen may be used for each of the tests.

729. The specimen shall not break or shatter when subjected to the impact, percussion or bending tests.

730. The specimen shall not melt or disperse when subjected to the heat test.

731. After each test, a leaching assessment shall be performed on the specimen by a method no less sensitive than the methods given in paras 736 and 737 .

\section{Test Methods}

732. Impact test: the specimen shall fall onto the target from a height of $9 \mathrm{~m}$. The target shall be as defined in para. 708 .

733. Percussion test: the specimen shall be placed on a sheet of lead which is supported by a smooth solid surface and struck by the flat face of a steel billet so as to produce an impact equivalent to that resulting from a free fall of $1.4 \mathrm{~kg}$ through $1 \mathrm{~m}$. The flat face of the billet shall be $25 \mathrm{~mm}$ in diameter with the edges rounded off to a radius of $3 \mathrm{~mm} \pm 0.3 \mathrm{~mm}$. The lead, of hardness number 3.5 to 4.5 on the Vickers scale and not more than $25 \mathrm{~mm}$ thick, shall cover an area greater than that covered by the specimen. A fresh surface of lead shall be used for each impact. The billet shall strike the specimen so as to cause maximum damage.
734. Bending test: the test is applicable only to long, slender sources with both a minimum length of $10 \mathrm{~cm}$ and a length to minimum width ratio of not less than 10 . The specimen shall be rigidly clamped in a horizontal position so that one half of its length protrudes from the face of the clamp. The orientation of the specimen shall be such that the specimen will suffer maximum damage when its free end is struck by the flat face of a steel billet.

The billet shall strike the specimen so as to produce an impact equivalent to that resulting from a free vertical fall of $1.4 \mathrm{~kg}$ through $1 \mathrm{~m}$. The flat face of the billet shall be $25 \mathrm{~mm}$ in diameter with the edges rounded off to a radius of $3 \mathrm{~mm} \pm 0.3 \mathrm{~mm}$.

735. Heat test: the specimen shall be heated in air to a temperature of $800^{\circ} \mathrm{C}$ and held at that temperature for a period of $10 \mathrm{~min}$. and shall then be allowed to cool.

\section{Leaching assessment methods}

736. For indispersible solid material:

(a) The specimen shall be immersed for 7 days in water at ambient temperature. The water shall have a $\mathrm{pH}$ of $6-8$ and a maximum conductivity of $10 \mu \mathrm{mho} / \mathrm{cm}$ at $20^{\circ} \mathrm{C}$.

(b) The water with specimen shall then be heated to a temperature of $50^{\circ} \pm 5^{\circ} \mathrm{C}$ and maintained at this temperature for 4 hours.

(c) The activity of the water shall then be determined.

(d) The specimen shall then be stored for at least 7 days in still air of humidity not less than $90 \%$ at $30^{\circ} \mathrm{C}$.

(e) The specimen shall then be immersed in water of the same specification as in (a) above and the water with specimen heated to $50^{\circ} \pm 5^{\circ} \mathrm{C}$ and maintained at this temperature for 4 hours. 
(f) The activity of the water shall then be determined.

The activities determined in (c) and (f) above shall not exceed $0.05 \mu \mathrm{Ci}$.

\section{For encapsulated material:}

(a) The specimen shall be immersed in water at ambient temperature. The water shall have a $\mathrm{pH}$ of $6-8$ with a maximum conductivity of $10 \mu \mathrm{mho} / \mathrm{cm}$. The water and specimen shall be heated to a temperature of $50^{\circ} \pm 5^{\circ} \mathrm{C}$ and maintained at this temperature for 4 hours. (b) The activity of the water shall then be determined.

(c) The specimen shall then be stored for at least 7 days in still air at a temperature not less than $30^{\circ} \mathrm{C}$.

(d) Repeat (a).

(e) The activity of the water shall then be determined.

These activities determined in (b) and (e) above shall not exceed $0.05 \mu \mathrm{Ci}$. 
NBS-114A (REV. 7.73)

\begin{tabular}{|c|c|c|c|}
\hline \begin{tabular}{l|c} 
U.S. DEPT. OF COMM. \\
BIBLIOGRAPHIC DATA \\
SHEET
\end{tabular} & $\begin{array}{l}\text { 2. Gov't Accession } \\
\text { No. }\end{array}$ & \multicolumn{2}{|c|}{ 3. Recipient"s Accession No. } \\
\hline \multicolumn{2}{|c|}{ 4. TITLE AND SUBTITLE } & \multicolumn{2}{|c|}{ 5. Publication Date } \\
\hline \multicolumn{2}{|c|}{ Sealed Radioactive Sources, Classification } & \multicolumn{2}{|c|}{ 6. Performing Organization Code } \\
\hline \multicolumn{2}{|l|}{$\begin{array}{l}\text { 7. AUTHOR(S) } \\
\text { Committee N43; E. H. Ejsenhower, Chairman } \\
\text { 9. PERFORMING ORGANIZATION NAME AND ADDRESS }\end{array}$} & \multicolumn{2}{|c|}{ 8. Performing Organ. Report No. } \\
\hline \multicolumn{2}{|l|}{$\begin{array}{l}\text { 9. PERFORMING ORGANIZATION NAME AND ADDRESS } \\
\text { NATIONAL BUREAU OF STANDARDS } \\
\text { DEPARTMENT OF COMMERCE } \\
\text { WASHINGTON, D.C. } 20234\end{array}$} & \multicolumn{2}{|c|}{$\begin{array}{l}\text { 10. Project/Task/Work Unit No. } \\
2400109\end{array}$} \\
\hline \multicolumn{2}{|c|}{ 12. Sponsoring Organization Name and Complete Address (Street, $C_{i t y}$, State, ZIP) } & \multicolumn{2}{|c|}{$\begin{array}{l}\text { 13. Type of Report \& Period } \\
\text { Covered } \\
\text { Final } \\
\end{array}$} \\
\hline \multicolumn{4}{|l|}{ 15. SUPPLEMENTARY NOTES } \\
\hline \multicolumn{4}{|c|}{$\begin{array}{l}\text { 16. ABSTRACT (A 200-word or less factual summary of most significant in formation. If document includes a significant } \\
\text { bibliography or literature survey, mention it here.) } \\
\text { This standard establishes a system of classification of sealed radioactive sources } \\
\text { based on performance specifications related to radiation safety. It provides a } \\
\text { manufacturer of sealed sources with a series of tests for evaluating the safety of } \\
\text { his product under specified conditions, and also assists a user of such sources to } \\
\text { select a type which suits the intended application insofar as maintenance of suurce } \\
\text { integrity is concerned. Tests are prescribed for temperature, external pressure, } \\
\text { impact, vibration, and puncture over a range of severity. Sealed source performance } \\
\text { requirements are identified for a variety of source applications, in terms of a } \\
\text { specific degree of severity of each test. Appendixes are included on the subjects } \\
\text { of leak test methods, quality assurance and control, brachytherapy sources, self- } \\
\text { luminous light sources, and special form radioactive material. }\end{array}$} \\
\hline \multirow{2}{*}{\multicolumn{4}{|c|}{$\begin{array}{l}\text { 17. KEY WORDS (six to twelve entries; alphabetical order; capitalize only the first letter of the first key word unless a proper } \\
\text { name; separated by semicolons) } \\
\text { Classification, leak test, national standard, radiation safety, radiation sources, } \\
\text { radioactive sources, radioactivity, sealed sources, standard. }\end{array}$}} \\
\hline & & & \\
\hline \multirow{3}{*}{$\begin{array}{l}\text { 18. AVAIL ABILITY } \\
\square \text { For Official Distribution. Do Not Release to NTIS } \\
\square \text { Order From Sup. of Doc., U.S. Government Printing Office } \\
\text { Washington, D.C. 20402, SD Stock No. SNO03-003 - O1903-8 }\end{array}$} & $\begin{array}{l}\text { 19. SECUR } \\
\text { (THIS R }\end{array}$ & $\begin{array}{l}\text { YCLASS } \\
\text { PORT) }\end{array}$ & 21. NO. OF PAGES \\
\hline & & & \\
\hline & $\begin{array}{l}\text { 20. SECUR } \\
\text { (THIS I }\end{array}$ & $\begin{array}{l}\text { Y CLASS } \\
\text { GE) }\end{array}$ & 22. Price \\
\hline $\begin{array}{l}\square \text { Order From National Technical Information Service (NTIS) } \\
\text { Springfield, Virginia 22151 }\end{array}$ & & & $\$ 1.20$ \\
\hline
\end{tabular}


. 


Order the following publications by SD Stock Number from:

Superintendent of Documents

U.S. Government Printing Office

Washington, D.C. 20402

American National Standard N43.2;

Radiation Safety for X-Ray Diffraction and Fluorescence Analysis Equipment.

NBS Handbook 111, Revised 1977. Price $\$ 1.00$,

SD Stock Number SN002-003-01917-8

American National Standard N543;

General Safety Standard for Installations Using Non-Medical $\mathrm{X}$-Ray and Sealed Gamma-ray Sources, Energies Up To $10 \mathrm{MeV}$.

NBS Handbook 114. Price: $\$ .90$,

SD Stock Number SN003-003-01377-3.

American National Standard N540;

Classification of Radioactive Self-Luminous Light Sources.

NBS Handbook 116. Price: $\$ 1.10$,

SD Stock Number SN003-003-01456-7.

American National Standard N537;

Radiological Safety Standard for the Design of Radiographic and Fluoroscopic Industrial X-Ray Equipment.

NBS Handbook 123. Price: $\$ .90$,

SD Stock Number SN003-003-01820-1.

American National Standard N433.1;

Safe Design and Use of Self-Contained, Dry Source Storage Gamma Irradiators.

NBS Handbook 127. Price: $\$ 1.10$

SD Stock Number SN003-003-01913-5

Order using "PB" from:

National Technical Information Service

5285 Port Royal Road

Springfield, VA 22161

American National Standard N43.1;

Radiological Safety in the Design and Operation of Particle

Accelerators.

NBS Handbook 107. Price: $\$ 4.00$,

PB 191-898 
U.S. DEPARTMENT OF COMMERCE

National Bureau of Standards

Washington, O.C. 20234

POSTAGE ANO FEES PAID

OFFICIAL BUSINESS

U.S. OEPARTMENT OF COMMERCE

COM-2I5

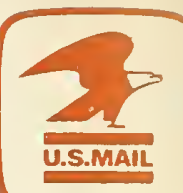

Penalty for Private Use, $\$ 300$

SPECIAL FOURTH-CLASS RATE

BOOK 